Original Article

Artigo Original

Camila Dantas Martins ${ }^{1}$

Renata Maria Moreira Moraes Furlan²

Andréa Rodrigues Motta ${ }^{3}$

Maria Cândida Ferrarez Bouzada Viana ${ }^{4}$

Keywords

Breast-feeding

Electromyography

Sucking Behavior

Facial Muscles

Stomatognathic System

Descritores

Aleitamento Materno

Eletromiografia

Comportamento de Sucção

Músculos Faciais

Sistema Estomatognático

Correspondence address:

Camila Dantas Martins

Rua São Lázaro, 1301/404, Bairro

Sagrada Família, Belo Horizonte (MG),

Brasil, CEP: 31035-580.

E-mail: mila.fonoufmg@ig.com.br

Received: 01/27/2015

Accepted: 02/28/2015

CoDAS 2015;27(4):372-7

\section{Electromyography of muscles involved \\ in feeding premature infants}

\author{
Avaliação eletromiográfica dos músculos envolvidos \\ na alimentação de recém-nascidos prematuros
}

\begin{abstract}
Purpose: To measure and compare the electrical activity of masseter, temporal, and suprahyoid muscles in premature newborn infants during breast-feeding and cup-feeding. Methods: This cross-sectional observational study was carried out by the electromyographic assessment of 36 preterm infants, 53\% of whom were male, with mean gestational age of 32 weeks and birth weight of $1,719 \mathrm{~g}$, fed via oral route, by full breast-feeding and supplementation of diet, through cup with expressed breast milk, until 15 days after hospital discharge. Children with neurological disorders, genetic syndromes, oral-motor, and/or congenital malformations were excluded. The different methods of feeding and the variables gestational age at birth, corrected gestational age, chronological age, birth weight and size, head circumference, and Apgar scores at 1 and 5 minutes were analyzed and compared by appropriate statistical analysis. Results: No difference was observed between breast-feeding and cup-feeding in the analysis of the temporal and masseter muscles. However, higher activity of suprahyoid musculature was observed during cup-feeding ( $\mathrm{p}=0.001$ ). The other variables were not correlated with the electrical activity of the muscles during the different feeding methods. Conclusion: There may be a balance between the activity of the temporal and masseter muscles during breast-feeding and cup-feeding. There was higher activity of suprahyoid musculature during cup-feeding. This can be explained by the greater range of tongue movement, as premature infants usually perform tongue protrusion to get the milk from the cup.
\end{abstract}

\section{RESUMO}

Objetivos: Mensurar e comparar a atividade elétrica dos músculos temporal, masseter e supra-hióideos de prematuros durante o aleitamento materno e por copo. Métodos: Estudo transversal observacional, realizado por meio da avaliação eletromiográfica de superfície em 36 prematuros, 53\% do gênero masculino, com idade gestacional média de 32 semanas e peso médio ao nascimento de $1.719 \mathrm{~g}$, em aleitamento misto, com suplementação de dieta por copo, até 15 dias após a alta hospitalar. Crianças com alterações neurológicas, síndromes genéticas, malformações craniofaciais, que utilizaram mamadeira, chupeta e/ou bico intermediário de silicone foram excluídas. A atividade elétrica dos músculos temporal, masseter e supra-hióideos foi comparada nos diferentes tipos de alimentação, entre os gêneros e entre as classificações do Apgar no $1^{\circ}$ e $5^{\circ}$ minuto e correlacionadas às variáveis idade gestacional ao nascimento, idade corrigida, idade cronológica, peso ao nascimento, estatura e perímetro cefálico ao nascimento. Resultados: Não houve diferença entre os métodos de alimentação avaliados quanto à atividade elétrica dos músculos temporal e masseter, no entanto verificou-se maior atividade da musculatura supra-hióidea durante a alimentação por copo $(\mathrm{p}=0,001)$. As demais variáveis não apresentaram correlação com a atividade elétrica dos músculos estudados durante os diferentes métodos de alimentação. Conclusão: Parece haver equilíbrio entre a atividade dos músculos temporal e masseter durante a alimentação ao seio materno e por copo. A musculatura supra-hióidea apresentou-se mais ativa no copo, o pode ser justificado pela maior amplitude de movimentação da língua, já que geralmente os RNPT realizam a protrusão da língua para obter o leite no copo.

Study carried out at the Speech Language Pathology and Audiology Ambulatory, Universidade Federal de Minas Gerais - UFMG - Belo Horizonte (MG), Brazil.

(1) Graduate Program in Health of the Child and Adolescent, Universidade Federal de Minas Gerais - UFMG Belo Horizonte (MG), Brazil.

(2) Graduate Program in Structure Engineering, Universidade Federal de Minas Gerais - UFMG - Belo Horizonte (MG), Brazil.

(3) Speech Language Pathology and Audiology Department, Universidade Federal de Minas Gerais - UFMG Belo Horizonte (MG), Brazil.

(4) Pediatrics Department, Universidade Federal de Minas Gerais - UFMG - Belo Horizonte (MG), Brazil. Conflict of interests: nothing to declare. 


\section{INTRODUCTION}

Breast feeding, due to its nutritional and immunological aspects, is the best source of food for the newborn (NB). Breastfeeding (BF) is considered the most appropriate feeding method for the development of the structures and functions of the stomatognathic system ${ }^{(1)}$, in addition to being important for stablishing a healthy mother-baby interaction ${ }^{(2)}$. The preterm neonate (PTNN), considered the risk, usually neurologically disorganized, may have absence of protection and/or feeding reflexes, thus, they may have difficulties in BF, being necessary the use of alternative feeding methods ${ }^{(3,4)}$. The safe feeding through oral route (OR) requires the maturation of the structures and functions of the stomatognathic system, and this maturity is related to the gestational age (GA) of the infant ${ }^{(5)}$. The successful feeding through OR is important for the neurobehavioral development of the PTNN and for their cognitive functions in the future ${ }^{(6)}$.

When the BF is not possible to be onset, whether by the absence of the mother at the moment of feeding, mammary alterations, maternal disease, among others, the cup is one of the methods recommended by the Ministry of Health to initiate the transition from the tube to the $\mathrm{OR}^{(7)}$. The United Nations Children's Fund and the World Health Organization have invested in the implementation of the Child Friendly Hospital Initiative, which approaches the offer of breast milk milked through the cup when it is not possible to breast-feed ${ }^{(8-10)}$. In a study carried out with the objective of comparing the feeding through glass and the $\mathrm{BF}$, it was verified that some tongue and jaw movements during the use of the cup are similar to those necessary to the successful BF and that the use of this tool reduces the time of use of probes and consequently the time of hospitalization ${ }^{(11)}$. Besides, studies have indicated that the use of the cup for BF supplementation is associated with the higher prevalence of $\mathrm{BF}$ at the moment of the hospital discharge ${ }^{(12)}$.

In clinical practice, no standardized method has been verified to be used in the transition for OR and/or supplementation of the diet in the Neonatal Progressive Care Nursery (NPCN). In a systematic review in which the use of the cup as an alternative feeding method for PTNN was evaluated, no consensus was found among the researchers in regard to the supplementation of the diet in this population through the use of these tools ${ }^{(13)}$. It is believed that the most appropriate method is the one that provides the safest and most efficient feeding way, with orofacial muscle activity most similar to the one used during BF.

An important tool to investigate the muscle activity of NBs and infants is the surface electromyography (sEMG) ${ }^{(10,14,15)}$. The sEMG refers to an objective method that evaluates the alterations in electrical potential from the skeletal muscle contraction; it is characterized by being a noninvasive and radiation-free test ${ }^{(16)}$. Its use in studies to determine the action of the oral muscles in the numerous feeding ways is recent, and few studies are available in the literature about the theme $e^{(10,17)}$. The studies carried out show similarities between the electrical muscle activity in BF and during cup-feeding ${ }^{(10,14,17)}$ and the reduced activity of the masseter muscle in the bottle-feeding than in the cup-feeding ${ }^{(17-20)}$.
A study carried out with PTNN ${ }^{(14)}$ evaluated the electrical activity of the masseter suprahyoid muscles during the use of the cup, translactation, and BF. No difference was observed in the activity of the muscles studied between the different kinds of feeding. Comparing the masseter and the suprahyoid muscles, the author concluded that there is a balance between the activity of these muscles during translactation and BF. In the use of the cup, another mechanism can be observed, the masseter muscle being more active than the suprahyoid muscles, suggesting that the translactation is a more physiological transition method to the OR. The author pointed out the need of a greater discussion on the feeding methods used in the transition of feeding among PTNNs and their influence on the muscles involved during BF, and, in further publications, proposed a protocol for the evaluation of the electrical activity of the masseter and the suprahyoid muscles in PTNN during feeding ${ }^{(15)}$.

As mentioned earlier, it becomes relevant to carry out new studies, which use objective tests, aiming at evaluating the activity of the muscles involved in the feeding processes of children, especially among preterms, once that these analyses are scarce and inconclusive. Thus, this study had the objective of measuring and comparing the electrical activity of the temporal, masseter, and suprahyoid muscles through an sEMG in preterms during BF and cup-feeding.

\section{METHODS}

It is an observational cross-sectional study, involving 36 PTNN, 53\% males and 47\% females, with GA at birth ranging from 27 to 36 weeks, and average weight at birth of $1,719 \mathrm{~g}$, who were born in the Hospital das Clinicas of the Universidade Federal de Minas Gerais, in Belo Horizonte, and remained hospitalized in the NPCN. The parents/guardians for the children, at the moment of hospital discharge, were invited to take part in the study. The research was carried out at the Speech Language and Audiology Laboratory of the institution, up until 15 days after the discharge, from August 2012 to July 2013.

The sample calculation was made by using the Stata software, version 10.0. The premises adopted were confidence interval of $95 \%$, error margin of 5\%, and a total of 36 children.

Patients who, at the time of birth, presented weight equal to or less than 2,500 g, GA equal to or less than 37 weeks, with up to 15 days after hospital discharge at the time of the test, who were under mixed BF, with supplementation of the cup, were included in this study. Those who had genetic syndromes and craniofacial malformations, and who used bottles and/or artificial silicone nipple between the date of hospital discharge and the test, besides those who were not able to go under sEMG for any reason, were excluded.

All NBs used orogastric and nasogastric probe for initial feeding, some kind of respiratory support, and were submitted to the evaluation and speech language and audiology intervention.

A portable eight-channel electromyography device (model EGM-800C; EMG Systems) was used, making use of only channels 1,2 , and 3 , referring to the temporal, masseter, and 
suprahyoid muscles, respectively. The suprahyoid muscle encompasses the digastric, stylohyoid, mylohyoid, and geniohyoid. The remaining channels were disabled.

We used disklike bipolar surface capture electrodes, pediatric, pre-jellified, disposable, by Hall. As a data collection material, the ground electrode by Medi-Trace, procedure gloves, disposable coffee cups, and gauze and alcohol 70\%, for the hygiene of the child's skin, were used. The test was carried out in a sound treated room, without electrical or electromagnetic interference, according to the recommendations of the sEMG for a noninvasive assessment of muscles (SENIAM) ${ }^{(21)}$.

The test consisted of the placement of a bipolar electrode on the surface of the skin, in the region of each of the researched muscles (temporal, masseter, and suprahyoid), unilaterally to the left, being this the side of the face the NB was not in contact with the maternal breast at the moment of the BF, reducing, thus, the interferences. The muscles evaluated were identified through touch. The electrodes were positioned over the muscles being studied, and the ground electrode, placed in the frontal region of the child ${ }^{(10)}$. The mothers were oriented to attend to the test between 2 and 3 hours before BF.

Initially, with the objective of removing the excessive oil and making the contact of the electrodes easier, the skin of the child was cleaned with gauze soaked in alcohol $70 \%{ }^{(21)}$. Thereafter, the muscles were identified, and the ground and surface electrodes were properly positioned. The electromyographic records occurred always in the same order, so that there was a standardization: $\mathrm{BF}$ and, later on, offering of milk from the cup. Each trial lasted 60 seconds. The mother was oriented to milk enough milk, before the beginning of the test, to complete the total volume of the cup $(60 \mathrm{~mL})$, avoiding the lack of milk during the data collection. During $\mathrm{BF}$, the mother was found in state of alert, sitting down, with their feet on the ground. The body of the child remained facing the front and close to the front of the mother, head and spine aligned with the chin close to the breast ${ }^{(22)}$. In cupfeeding the NB, in state of alert, remained sitting down on the researcher's lap. The edge of the cup was touched to the lips of the child and it was waited until they would drink the milk $\mathrm{k}^{(7)}$. The positioning to the maternal breast and the offering of diet through cup was carried out by the same researcher. The stabilizing of child was waited and then the recordings began. The time spent during the electromyographic evaluation, including the procedures that preceded it, lasted approximately 40 minutes.

The acquisition of the signal was performed with the sample rate of $1,000 \mathrm{~Hz}$. Then, the signal was filtered $(20-500 \mathrm{~Hz})$, rectified, and sent to a microcomputer where it was processed by a specific software for the acquisition and processing of the data (Software AqDados, version 5.05; Lynx Tecnologia Eletrônica LTDA ${ }^{\circledR}$ ). The variable analyzed in this research was the value of the root mean square (RMS) of the electromyographic signal, calculated by the software, RMS being the square root of the squares of the signal throughout the whole measurement ${ }^{(16)}$.
The mean values of RMS for the temporal, masseter, and suprahyoid muscles were compared between the feeding methods (breast and cup) and between the gender and Apgar variables at the first and fifth minutes of life for both evaluated feeding methods. For the comparison of the Apgar at the first minute, the individuals were grouped into the following categories: Apgar from 1 to 3, from 4 to 7, and from 8 to 10. For the comparison of Apgar at the fifth minute, the individuals were grouped into the following categories: Apgar from 4 to 7 and from 8 to 10 .

In the statistical analysis, measures of central and dispersion trends were used. For the groups with normal distribution, as a hypothesis test, we used the paired $t$-test and analysis of variance for the comparison of the groups. We used the linear correlation coefficient of Spearman with the objective of measuring the degree of association or mutual linear relation between the two variables. The value of $p<0.05$ was adopted as significance level in all analyses.

The research was approved by the ethics committee of the Universidade Federal de Minas Gerais under the number CAAE - 0597.0.203.000-11. All parents and legal guardians of the children signed the informed consent.

\section{RESULTS}

In Table 1, the findings related to the continuous variables analyzed in this study are described.

In Table 2, the means of the electrical activity of the temporal, masseter, and suprahyoid muscles in PTNN during the $\mathrm{BF}$ and the cup-feeding are presented. When comparing both feeding methods and the muscle groups evaluated, we obtained a difference only for the suprahyoid muscles $(\mathrm{p}=0.001)$, noticing greater activity of these muscles during cup-feeding.

When comparing the mean of electrical activity of the temporal, masseter, and suprahyoid muscles, during BF and cup-feeding, between the gender variables, Apgar in the first and fifth minutes of life (Table 3), we observed no difference.

The values of the Spearman correlation coefficient for the variables weight at birth, height, head circumference, GA at birth, chronological age, and corrected GA presented low values and did not indicate association between these variables and the electrical activity of the temporal, masseter, and suprahyoid muscles in both the feeding methods being studied (Table 4).

Table 1. Descriptive analysis refers to the continuous variables: weight at birth, height, head circumference, gestational age at birth, chronological age, and corrected gestational age

\begin{tabular}{lcc}
\hline Variable & Minimum & Mean (SD) \\
\hline Weight at birth $(\mathrm{g})$ & 855 & $1,719.3(435.83)$ \\
Height $(\mathrm{cm})$ & 36 & $41.4(2.96)$ \\
Head circumference (cm) & 23 & $29.6(2.54)$ \\
Gestational age (weeks) & 27 & $32.2(2.36)$ \\
Chronological age (days) & 15 & $34.3(17.54)$ \\
Corrected gestational age (weeks) & 31 & $37.1(2.36)$ \\
\hline
\end{tabular}

Caption: SD = standard deviation 
Table 2. Comparison between the different feeding methods (breast and cup) and the mean of electrical activity of the temporal, masseter, and suprahyoid muscles (in $\mu \mathrm{V}$ )

\begin{tabular}{lccc}
\hline \multirow{2}{*}{ Variable } & Breast & Cup & \multirow{2}{*}{ p-value } \\
\cline { 2 - 3 } & Mean (SD) & Mean (SD) & \\
\hline Temporal & $0.0088(0.0068)$ & $0.0510(0.1291)$ & 0.058 \\
Masseter & $0.0088(0.0014)$ & $0.0189(0.0440)$ & 0.173 \\
Suprahyoid & $0.0114(0.0088)$ & $0.0475(0.0597)$ & $0.001^{*}$ \\
\hline
\end{tabular}

${ }^{*} t$-Test

Caption: SD = standard deviation

Table 3. Comparison between the variables of gender, Apgar values in the first and fifth minutes of life, in relation to the mean of the electrical activity of the temporal, masseter, and suprahyoid muscles $(\mu \mathrm{V})$ for both the evaluated feeding methods

\begin{tabular}{|c|c|c|c|}
\hline \multirow{2}{*}{ Variables } & Temporal & Masseter & Suprahyoid \\
\hline & \multicolumn{3}{|c|}{$p$-value } \\
\hline \multicolumn{4}{|l|}{ Breast } \\
\hline Gender* & 0.962 & 0.788 & 0.516 \\
\hline \multicolumn{4}{|c|}{ Apgar $1^{\text {st }}$ minute ${ }^{\star *}$} \\
\hline \multicolumn{4}{|l|}{8 to 10} \\
\hline \multicolumn{4}{|c|}{ Apgar $5^{\text {th }}$ minute ${ }^{\star *}$} \\
\hline $\begin{array}{l}4 \text { to } 7 \\
8 \text { to } 10\end{array}$ & 0.960 & 0.488 & 0.720 \\
\hline \multicolumn{4}{|l|}{ Cup } \\
\hline Gender* & 0.936 & 0.342 & 0.096 \\
\hline \multicolumn{4}{|c|}{ Apgar $1^{\text {st }}$ minute ${ }^{\star *}$} \\
\hline \multicolumn{4}{|l|}{8 to 10} \\
\hline \multicolumn{4}{|c|}{ Apgar $5^{\text {th }}$ minute ${ }^{* *}$} \\
\hline $\begin{array}{l}4 \text { to } 7 \\
8 \text { to } 10\end{array}$ & 0.646 & 0.727 & 0.482 \\
\hline
\end{tabular}

${ }^{*} t$-Test; ${ }^{* *}$ ANOVA test

\section{DISCUSSION}

No significant differences were found in this study between the electrical activity of the temporal and masseter muscles when comparing BF to cup-feeding. In relation to the suprahyoid muscles, a higher activity was verified during cup-feeding, this being a significant data. Such finding may be justified by the higher range of movement of the tongue during cup-feeding when compared to suction. During cup-feeding, usually, between the PTNN the protrusion of the tongue is observed to obtain milk. Later on, this movement is replaced by the movement of absorption ${ }^{(23)}$.

In a research through which the activity of the masseter, temporal, and buccinator muscles during BF, bottle-feeding, and cup-feeding was measured, using the sEMG, the author concluded there was similarity between the muscle activity of the group in BF and during cup-feeding ${ }^{(10)}$, which agrees to the findings of this study for the masseter and temporal muscles.

A study that analyzed the electrical activity of the masseter and suprahyoid muscles, during cup-feeding, translactation, and BF, no difference was observed in the activity of the muscles studied between the different types of feeding. These findings are different from the ones found in this study, once the electrical activity of the suprahyoid muscles was more active with cup-feeding. The author also compared the electrical activity between the masseter and suprahyoid muscles during the different feeding methods and found a significant difference between the activities of the masseter and the suprahyoid muscles during cup-feeding, with higher activity of the masseter muscle. The author concluded that there is a balance between the activities of the masseter and the suprahyoid muscles during feeding by translactation and in BF. In cup-feeding, there seems to be another mechanism of activity of these muscles, considering that the masseter

Table 4. Spearman correlation between the epidemiological and physical variables and the mean electrical activity of the temporal, masseter, and suprahyoid muscles $(\mu \mathrm{V})$ for both the feeding methods evaluated

\begin{tabular}{|c|c|c|c|c|c|c|}
\hline \multirow{2}{*}{ Variables } & \multicolumn{2}{|c|}{ Temporal } & \multicolumn{2}{|c|}{ Masseter } & \multicolumn{2}{|c|}{ Suprahyoid } \\
\hline & $\rho$ & $\mathrm{p}$-value & $\rho$ & $\mathrm{p}$-value & $\rho$ & $p$-value \\
\hline \multicolumn{7}{|l|}{ Breast } \\
\hline Weight at birth (g) & -0.108 & 0.53 & 0.073 & 0.67 & -0.129 & 0.45 \\
\hline Height $(\mathrm{cm})$ & -0.219 & 0.19 & -0.051 & 0.77 & -0.201 & 0.23 \\
\hline Head circumference $(\mathrm{cm})$ & -0.116 & 0.49 & 0.028 & 0.86 & -0.012 & 0.94 \\
\hline Gestational age (weeks) & -0.097 & 0.57 & 0.112 & 0.51 & -0.165 & 0.33 \\
\hline Chronological age (days) & 0.261 & 0.12 & 0.053 & 0.74 & 0.128 & 0.45 \\
\hline Corrected gestational age (weeks) & 0.097 & 0.57 & -0.112 & 0.51 & 0.165 & 0.33 \\
\hline \multicolumn{7}{|l|}{ Cup } \\
\hline Weight at birth (g) & 0.035 & 0.84 & -0.008 & 0.96 & -0.123 & 0.47 \\
\hline Height $(\mathrm{cm})$ & -0.075 & 0.66 & -0.085 & 0.62 & -0.191 & 0.26 \\
\hline Head circumference $(\mathrm{cm})$ & 0.022 & 0.90 & 0.027 & 0.87 & 0.062 & 0.71 \\
\hline Gestational age (weeks) & 0.003 & 0.98 & 0.093 & 0.58 & -0.067 & 0.69 \\
\hline Chronological age (days) & -0.021 & 0.90 & -0.059 & 0.72 & 0.056 & 0.74 \\
\hline Corrected gestational age (weeks) & -0.003 & 0.98 & -0.093 & 0.58 & 0.067 & 0.69 \\
\hline
\end{tabular}

Caption: $\rho=$ Spearman correlation coefficient 
muscles are more active than the suprahyoid ones, which suggests that translactation seems to be a more physiological method when compared to $\mathrm{BF}^{(14)}$.

When comparing the electrical activity of the evaluated muscles in both the studied feeding methods and the score of Apgar in the first and fifth minutes of life, no significant relations were observed. These data, however, differ from the findings of a study analyzing the factors that could influence the BF among PTNN. The authors verified that these factors include the maternal diseases, obstetric complications, and the score of Apgar in the first minute of life ${ }^{(24)}$. The Apgar score in the first minute may be related to the maturation of the structures and functions of the stomatognathic system, interfering, therefore, on BF success. The fact that no correlation was found between these two variables may be related to the reduced number of PTNN with Apgar score below 4.

The sample variables GA at birth, corrected age, chronological age, weight at birth, and height and head circumference at birth do not present correlation with the electrical activity of the muscles studied during the different feeding methods. The articles measuring the electrical activity of the muscles involved in the feeding of NBs do not investigate this relation. A relevant aspect of the research refers to the fact that both feeding methods were evaluated in the same population, to reduce the confounding variables.

In the institution where this study was conducted, the method of choice in the transition from OR is the suction of the maternal breast. When BF is not possible, the cup is a preconized method as it regards a friendly hospital of the child. This way, the use of a bottle was not evaluated in this study. In a research that evaluated the electrical activity of the masseter muscle of infants born at term during BF and bottle-feeding, the authors verified low activation of the masseter muscle during bottle-feeding when compared to BF and emphasized that such fact may compromise the development of the masticatory function ${ }^{(19)}$. The same way, other authors ${ }^{(20)}$, when studying the electrical activity of the temporal, masseter, orbicularis oris, and suprahyoid muscles in babies born at term in exclusive BF, bottle-feeding, and mixed feeding, verified that the masseter muscle presented reduced electrical activity in bottle-feeding when compared to BF. Another finding of the literature refers to the hyperfunction of the buccinator muscle in bottle-feeding, verifying in a research that evaluated the temporal, masseter, and buccinator muscles during the BF, cup-feeding, and bottle-feeding of infants born at term ${ }^{(10)}$.

Because it is an objective, non-invasive, fast and radiationfree method ${ }^{(16)}$, the sEMG was the instrument chosen in this study to evaluate the differences between the electrical activity of the temporal, masseter and suprahyoid muscles during BF and cup-feeding. In the literature researched, it was observed that the studies using the sEMG in the feeding process of PTNN are scarce ${ }^{(17)}$.
In this study, there was no normalization because for its calculation a voluntary maximum contraction of a given muscle is necessary ${ }^{(21)}$ and this contraction is impossible in this kind of population. The limitations of this study include not having considered the hospitalization time, the time at which the NB was fed by probe, the time at which they were fed by OR, and the time since the hospital discharge to the test.

Other studies using the sEMG are required as it is an objective test, with larger samples when compared to other feeding methods, especially between the PTNN, so that the most physiological method determined in the transition into OR and/or dietary supplementation for this population, ensuring thus the success of BF.

\section{CONCLUSION}

The results indicate there is a balance between the activity of the temporal and masseter muscles during BF and cupfeeding. The suprahyoid muscles presented themselves as more active in cup-feeding, which may be justified by the wider range of movement of the tongue, as usually the PTNN perform the protrusion of the tongue to obtain milk during the feeding with this tool.

*CDM was responsible for the design of the study, for the collection, tabulation, and analysis of the data, as well as for the elaboration of the manuscript; RMMF helped in the design of the study, and in the collection and tabulation of the data; MCFBV and ARM were responsible for the project, design of the study, and overall guidance of the execution stages.

\section{REFERENCES}

1. Carvalho GD. Amamentação e o sistema estomatognático. In: Carvalho MR, Tamez RN. Amamentação: bases científicas para a prática profissional. Rio de Janeiro: Guanabara-Koogan, 2002. p. 37-49.

2. Reyna BA, Pickler RH. Mother-infant synchrony. J Obstet Gynecol Neonatal Nurs. 2009;38(4):470-7.

3. Hernandez AM. Atuação fonoaudiológica em neonatologia: uma proposta de intervenção. In: Andrade CRF. Fonoaudiologia em berçário normal e de risco. São Paulo: Lovise, 1996. p. 43-95.

4. Neiva FCB. Neonatologia: Papel do fonoaudiólogo no berçário. São José dos Campos: Pulso, 2004. p. 225-234.

5. Amaizu N, Shulman RJ, Schanler RJ, Lau C. Maturation of oral feeding skills in preterm infants. Acta Paediatr. 2008;97(1):61-7.

6. Pickler RH, McGrath JM, Reyna BA, McCain N, Lewis M, Cone S, et al. A model of neurodevelopmental risk and protection for preterm infants. J Perinat Neonat Nurs. 2010;24(4):356-65.

7. Brasil. Ministério da Saúde. Secretaria de Atenção à Saúde. Departamento de Ações Programáticas Estratégicas. Atenção humanizada ao recém-nascido de baixo peso: método canguru. 3. ed. Brasília: Editora do Ministério da Saúde, 2013.

8. Lang S. Aleitamento do lactente: cuidados especiais. São Paulo: Editora Santos, 1999.

9. Dowling DA, Meier PP, Difi JM, Blatz M, Martin RJ. Cup feeding for preterm infants: mechanics and safety. J Hum Lact. 2002;18(1):13-20.

10. Gomes CF, Trezza EMC, Murade ECM, Padovani CR. Surface electromyography of facial muscles during natural and artificial feeding of infants. J Pediatr. 2006;82:103-9. 
11. Kuehl J. Cup feeding the newborn: What you should know. J Perinat Neonatal Nurs. 1997;11(2):56-60.

12. Pedras CTPA, Pinto EALC, Mezzacappa MA. Uso do copo e da mamadeira e o aleitamento materno em recém-nascidos prematuros e a termo: uma revisão sistemática. Rev Bras Saúde Matern Infant. 2008;8(2):163-9.

13. López CP, Silva RG. Métodos de alimentação alternativa para recémnascidos prematuros. Rev Paul Pediatr. 2012;30(2):278-82.

14.Raposo RD. Atividade dos músculos masséter e supra-hioideos em recémnascidos pré-termo durante o uso do copinho, da translactação e na amamentação. [Tese]. Recife: Universidade Federal de Pernambuco; 2012.

15. Raposo RD, Silva HJ. Proposta de um protocolo de avaliação da atividade elétrica dos músculos masseter e supra-hióideos em recém-nascidos prétermo durante a alimentação. Rev CEFAC. 2013;15(4):803-14.

16. Rahal A, Pierotti S. Eletromiografia e cefalometria na Fonoaudiologia. In: Ferreira LP, Befi-Lopes DM, Limongi SCO (organizadores). São Paulo: Roca; 2004. p. 237-53.

17. Gomes CF, Thomson Z, Cardoso JR. Utilization of surface electromyography during the feeding of term and preterm infants: a literature rewiew. Dev Med Child Neurol. 2009;51:936-42.
18. Inoue N, Sakashita R, Kamegai T. Reduction of masseter muscle activity in bottle-fed babies. Early Hum Dev. 1995; 18:185-93.

19. Sakashita R, Kamegai T, Inoue N. Masseter muscle activity in bottle feeding with the chewing type bottle teat: evidence from electromyographs. Early Hum Dev. 1996;45:83-92.

20. Tamura Y, Horikawa Y, Yoshida S. Co-ordination of tongue movements and peri-oral muscle activities during nutritive sucking. Dev Med Child Neurol. 1996;38:503-10

21. Hermens HJ, Freriks B, Disselhorst-Klug C, Rau G. Development of recommendations for SEMG sensors and sensor placement procedures. J Electromyogr Kinesiol. 2000;10:361-74.

22. WHO [Internet]. Promovendo o aleitamento materno [cited 2013 Jan 12]. Available from: www.bvsms.saude.gov.br/bvs/publicacoes/album seriado_aleitamento_maternpdf

23. Lang S, Lawrence CJ, Orme RL. Cup feeding: an alternative method of infant feeding. Arch Dis Child. 1994;71:365-9.

24. Jang GJ, Lee SL, Kim HM. Breast feeding rates and factors influencing breast feeding practice in late preterm infants: comparison with preterm born at less than 34 weeks of gestational age. J Korean Acad Nurs. 2012;42(2):181-9. 